\title{
Legal Issues and Scientific Constraints in the Environmental Assessment of the Deepwater Horizon Oil Spill in Mexico Exclusive Economic Zone (EEZ) in the Gulf of Mexico
}

\author{
Luis A. Soto, Alfonso Vázquez-Botello \\ UA-Oceanic and Coastal Processes-Instituto de Ciencias del Mar y Limnología, \\ Universidad Nacional Autónoma de México, México, D.F., México \\ Email: lasg@cmarl.unam.mx
}

Received July 2013

\begin{abstract}
The largest accidental marine oil spill (4.9 million barrels) in the Gulf of Mexico (GoM) seabed (1600 m) caused by the sinking of the Deepwater Horizon oil rig in 2010, put to the test once again the resilient capacity of the pelagic and benthic realms of this Large Marine Ecosystem. Many are the ecological services provided by its waters (fisheries, tourism, aquaculture and fossil fuel reserves) to neighboring countries (US, Mexico and Cuba). However, the unprecedented volumes of hydrocarbons, gas and chemical dispersants (Corexit) introduced in the system, represent ecological stressors whose deleterious effects are still the subject of civil claims and scientific controversy. Presumably, the short scale effects were confined to the Gulf's northeastern shallow waters, and the combined actions of weathering, biodegradation, and oil recovery left the system almost under pre-spill conditions. Unfortunately, surface and subsurface oil plumes were detected in the spill aftermath, and their dispersion trajectories threatened Mexico EEZ. Surface oil slicks were detected in the pristine waters of northern Yucatán, while subsurface oil plumes from the Macondo's well blowout were dangerously advancing southwest towards key fishing grounds in the northwestern GoM. This disaster prompted the Mexican government to implement an ambitious ocean monitoring program adopting a bottom-up approach focused on building a base line for more than 42 physicochemical and biological variables for water, sediment and biota from the continental shelf-slope region of the NW GoM. Technological constraints have precluded systematic observations in the vast Mexican EEZ that could discriminate natural variability and oil seep emissions from antropic disturbances. Therefore, preliminary risk analyses relied on seasonal and historical records. Two years of field observations revealed subtle environmental changes in the studied area attributed to antropic disturbances. Waters maintained oligotrophic conditions and zooplankton and benthic infaunal biomass were also poor. Biomarkers in sediments and biota did not exceed EPA's benchmarks, and sediment's fingerprinting $\left(\delta^{13} \mathrm{C}\right)$ indicated marine carbon sources. Geomarkers revealed an active transport from the Mississippi towards the NW GoM of phyllosilicates bearing a weathered oil coating. Consequently, shelf and slope sediment toxicity begins to show an increasing trend in the region. The complexity of hydrocarbons bioaccumulation and biodegradation processes in deep waters of the GoM seems to indicate that meso- and large-scale observations may prove to be essential in understanding the capacity of the GoM to recover its ecological stability.
\end{abstract}

Keywords: Deepwater Horizon; Macondo’s Oil Spill Accident; Mexico’s Exclusive Economic Zone; Gulf of Mexico

\section{Introduction}

The oil spill caused by the sinking of the Deepwater Horizon Platform (DWH) in the northern Gulf of Mexico (GoM) is unprecedented in the history of catastrophic events in the marine environment in both coastal and deep-waters. The assessment of the environmental consequences caused by this spill has represented a major challenge for the scientific community of the neighboring countries sharing the waters and resources of this Large Marine Ecosystem.

The precise volume of oil spilled and the trajectory of surface and subsurface oil slicks are still controversial issues. Similarly, the persistence in time and space of weathered oil, its by-products, and their environmental effects, constitute major research uncertainties for most of the current studies hitherto accomplished. In the aftermath of the oil spill accident, the reports released by 
U.S. agencies NOAA and EPA [1,2] offered to the general public a rather optimistic assessment on the percentages of recovered oil, the volume burned and evaporated from the Macondo's well blowout [3,4]. Nonetheless, there was a tacit admission about the severe environmental damages caused by the accumulation of oil on shorelines of the coastal zone of the northeastern GoM. In spite of this environmental emergency, that lasted for more than four months, there was a consensus among experts [5-7], that while the expected damage in the coastal zone was not as severe as anticipated, it was recognized that the Corexit dispersant injected near the base of the oil well, promoted the formation of subsurface hydrocarbon plumes, whose dispersion and degradation in the deep sea was enigmatic given our limited knowledge on deep water circulation of the GOM.

Under this appalling scenario, the Mexican government implemented in the summer of 2010, an ambitious ocean monitoring program covering its own Exclusive Economic Zone in the GoM. Initially a bottom-up approach was adopted in a multidisciplinary research program focused on building a base line for more than 42 physicochemical and biological variables for water, sediment and biota obtained from the continental shelfslope region of the NW GoM. The present study highlights the most relevant environmental issues related to the Macondo’s oil spill from a Mexican perspective.

\section{Background}

The GoM is one of the 61 Large Marine Ecosystems (LME) recognized on the Planet. These ecosystems are relatively large oceanic units characterized by environ- mental properties such as bathymetric conditions, hydrographic, productivity and trophically dependent populations [8]. In the particular case of the Go M, its waters are shared by three countries, the U.S., Mexico and Cuba, and much of the economy of these nations revolves around energy and fishery resources from the coastal zone and the ocean's seabed.

The DWH well blow out located just off the Mississippi River Delta spilled for nearly 84 days, 4.3 million barrels of crude oil and an equivalent amount of methane gas. As part of the first mitigation procedures it was decided to employ 2.1 million gallons of chemical dispersants both on the surface, and at the base of the well [7]. This last action provoked the formation of hydrocarbon subsurface oil plumes [9,10], approximately $100 \mathrm{~m}$ wide, with a southwest trajectory and an estimated speed of 4 NM/ day [11,12].

According to our own projections [13,14], based on the surface circulation models of the waters of the GoM, the regions most likely to receive in the mid-term, the impact of the oil slick from the Macondo's blowout, were the NE and SW coasts of Mexico. Our own research efforts in the first two years of monitoring were concentrated in the NW sector of the GoM (Figure 1). This sector of the GoM is strongly influenced by the cyclone and/or anticyclone gyres derived from the Loop Current. When these processes are absent in the NW Gulf, the surface oceanic circulation is predominantly towards the north. Gyres in the NW Gulf are known for their significant time/space variability. The salinity and density vertical profiles obtained in winter indicated the intrusion of cold and more diluted water originated from the Louisiana-Texas continental shelf.
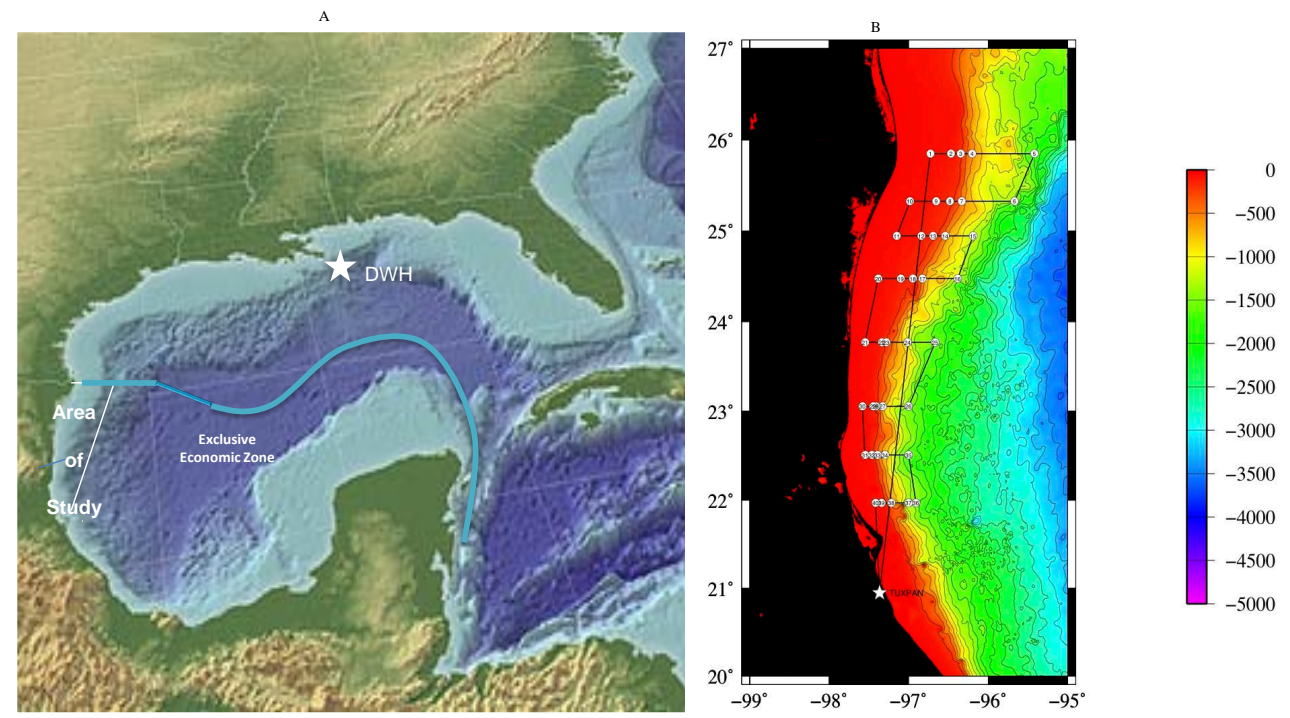

Figure 1. A. Location of the area of study in the NW. Gulf of Mexico. The extension of Mexico's Exclusive Economic Zone and the approximate position of the Deepwater Horizon Platform (DWH) are indicated. B. Position of the oceanographic stations on the continental shelf and slope of the NW Gulf of Mexico (depth scale in meters). 
It is worth noting to indicate at this point the technical difficulties involved in the identification of Macondo's crude oil once it was over dispersed by surface and bottom currents, and exposed to weathering and biodegradation processes. This situation seems augmented by the facts that in the GoM there are natural emission of hydrocarbons and gas [15]. Sometimes the geochemical record of GoM sediments reflects a composition of vegetable waxes, biofilms, and weathered hydrocarbons from subsurface natural filtrations beneath the seabed. In the particular case of the Macondo's blowout, the environmental damage assessment is also magnified by mixing processes and fractionating of the oil components [16-18].

Fortunately, there is valuable oceanographic information [13,14,19-22] available from the regions under study (SW marine ecosystem-Campeche Sound , and the NW sector-continental shelf of Tamaulipas and Veracruz) that documents the pre-spill environmental conditions of the GoM.

\section{Main Oceanographic Features in Mexico's EEZ: NW Gulf of Mexico}

The Gulf of Mexico is one of the most productive water bodies on earth. Its area is about 1.5 million $\mathrm{km}^{2}$, with a maximum depth of 3,800 $\mathrm{m}$ in the area known as Sigsbee Abyssal Plain. It is relevant to note, that the valuable natural resource of the GoM are also exposed to the action stressful natural chemical and biological factors whose synergy causes environmental changes with a certain degree of predictability (seasonality). There are also catastrophic weather events such as storms and hurricanes, which modify the coastline, and can alter the patterns of sediment transport, thus promoting erosion. Its water chemical balance can also be altered by the extraction of fossil fuels and gas beneath the seabed.

In recent years, excessive discharge of organic materials (fertilizers) in areas near the Mississippi River [23] and Coatzacoalcos have generated the formation of hypoxic areas in which the $\mathrm{O}_{2}$ concentration level drops alarmingly, threatening the survival of communities occupying the marine seabed. In reference to the Tamaulipas and northern Veracruz coasts (Figure 1), these are highly influenced by river discharges (Bravo, Soto la Marina, Pánuco) that enrich with nutrients and organic matter the waters of the adjacent continental shelf. The continental shelf in this region is narrow with a maximum length of $50 \mathrm{~km}$ and with steep and rugged slopes, particularly off the coast of northern Veracruz. The sedimentary environment in the coastal strip is dominated by terrigenous input from rivers and lagoons; sand and biogenic muds predominate in deeper areas (Figure 2).

Other major physiographic features in the GoM are the presence of extensive coastal lagoons namely Laguna Madre and Tamiahua; both function as natural nursery grounds for many estuarine-dependent species (penaeid shrimp and oysters). The waters of the continental shelf in this region of the GoM exhibit stratification and mixing conditions from April to September and November to March, respectively. During the rainy season (June-September), the rivers have a significant dilution and cooling effects in the salinity (30 psu) and temperature of the river plume $\left(23^{\circ} \mathrm{C}\right)$. Due to the intrusion of ocean water toward the coast, these parameters are maintained at $23^{\circ} \mathrm{C}$ and $36 \mathrm{psu}$, and shallow seasonal thermocline (18 $\mathrm{m})$. Winter northern fronts promote the mixing of the water column causing low salinity and temperature (34 psu and $15^{\circ} \mathrm{C}$ ) and the deepening of the thermocline (80 to $160 \mathrm{~m}$ ). The waters of this region are considered well ventilated to $100 \mathrm{~m}$, with oxygen concentrations of 4 - 5 $\mathrm{ml} \cdot \mathrm{L}^{-1}$. The reference values of nutrients $\left(\mathrm{PO}_{4}, \mathrm{NO}_{3}, \mathrm{NO}_{2}\right.$, and $\mathrm{SiO}_{2}$ ) tend to be more enriched during the mixing phase of the water column, reducing its concentration values when stratified conditions are established. There is a positive correlation between significant nutrient values and sites under the influence of river and lagoon discharges. However, the rapid consumption of nutrients by neritic phytoplankton maintains oligotrophic conditions. The surface concentration values of chlorophyll a $(>0.10$ $\mathrm{mg} \cdot \mathrm{m}^{-3}$ ) correlate well with sites receiving low fluvial influence, while oceanic environments are characterized by poor chlorophyll concentrations $\left(<0.05 \mathrm{mg} \cdot \mathrm{m}^{-3}\right)$.

A vital information in this study are the reference concentrations of heavy metals and polycyclic aromatic hydrocarbons (PAH's) in surface sediments previously recorded in the study area. Heavy metals such as $\mathrm{Cr}, \mathrm{Ni}$, and $\mathrm{Cd}$ reach significant concentrations along the Tamaulipas' shelf [24]. There are also high levels (26.9 $\left.\mu \mathrm{g} \cdot \mathrm{g}^{-1}\right)$ of PAH's in sediments off Tamaulipas and Veracruz attributable to chronic oil spills in the area.

\section{Economic Damage Assessment}

The estimation of natural resource damages caused by oil spills is extremely controversial. The main difficulty resides in the complexity involved in assessing the ecological services offered by the different biotic components of the marine ecosystem. An event such as the Macondo's oil spill is subject of legal claims from physical damages, cleanup and preventative actions to the loss of fishing grounds and landscape property value. According to international agreements (International Oil Pollution Fund) and US federal legislation (Oil Pollution Act, 1990) addressing oil spill accidents, the responsible party, British Petroleum in this case, can be held accountable for the caused environmental damages, while the affected parties must provide sufficient evidence of the source of 

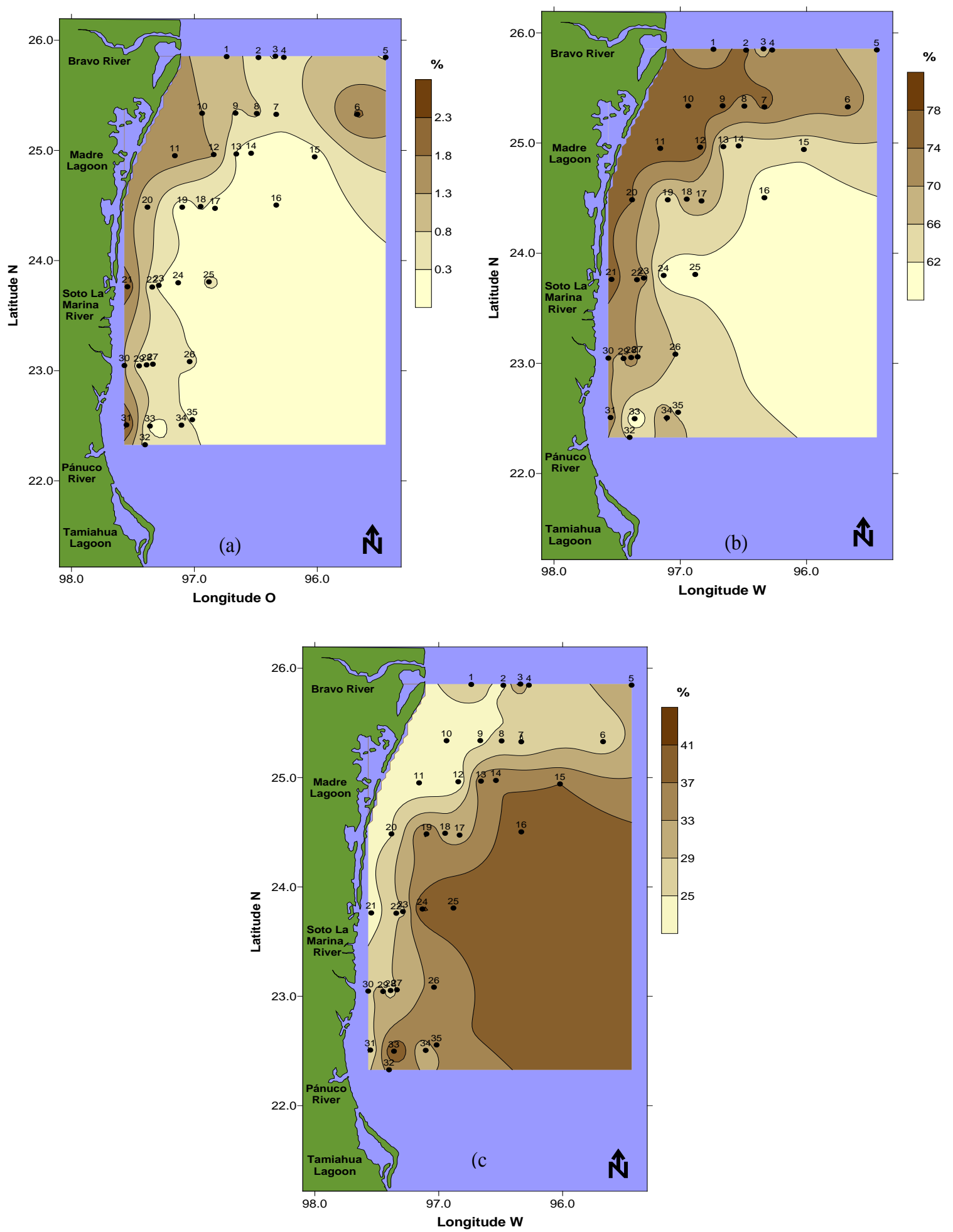

Figure 2. Distribution and composition of surface sediments in the NW Gulf of Mexico. (a) Sand. (b) Silt. (c) Clay.

the spilled oil, and an economic quantification of the alleged damages. Sumaila et al. (2012) have briefly explained some of the various attempts made in assessing economic environmental damages due to oil spills. Apparently, accidents caused by oil tankers are highly vari- able in nature. They depend on the type of oil, the volume spilled and the area where the accident occurs. While oil rig accidents like the Deepwater Horizon platform, located in a "sensitive ecoregions" have substantial ecological and economic damages [25]. 


\section{General Discussion}

The Large Marine Ecosystem Gulf of Mexico is a semi-enclosed basin whose hydrodynamic and topographic features may contribute to the confinement or the dispersion of crude oil. Thus for instance, it was assumed that the circulation system prevailing in the summer in the northern gulf was responsible for the hydrocarbon concentration towards the northeast [1], where oil slick remains were then trapped into the Eddy Franklin, a major gyre system of the Loop Current. Satellite images obtained in June, 2010 revealed oil residues at $200 \mathrm{~km}$ north of Yucatan [26] possibly transported by this circulation system.

Perhaps, during the summer the surface transport of Macondo's crude oil was not as intense towards the northwestern GoM. However, in the mid-term, such transportation could have taken place through the subsurface layers below the mixed layer $(\sim 500 \mathrm{~m})$. We were able to detect in the winter of 2011, the transport and deposition of oil mineral aggregates (OMA) in the EEZ of Mexico on the slope (>1000 m) in front of Tamaulipas (Figure 3). Presumably, the intrusion of water from Texas-Louisiana shelf observed in winter, favored these processes. Interestingly enough, at this time of year, an increasing gradient in the levels of sediment toxicity was also recorded in that region of the GoM [27].

The Mexican waters and coastal environments in the GOM have been internationally recognized for its megabiodiversity. These habitats are home to over 15,000 species of flora and fauna and many of them have considerable commercial value. That is the case of the penaeid shrimp populations exploited in the offshore waters of Tamaulipas, Veracruz, Campeche and Quintana Roo. Other important fishing resources of high economic value are the pelagic stocks of red snapper, grouper and tuna. The blue crab, oysters, and clams, which are normally exploited in the complex lagoon systems around the gulf (Laguna Madre-Tamiahua-Alvarado), constitute vital artisanal fisheries. All these marine living resources are highly vulnerable to toxic compounds incorporated into

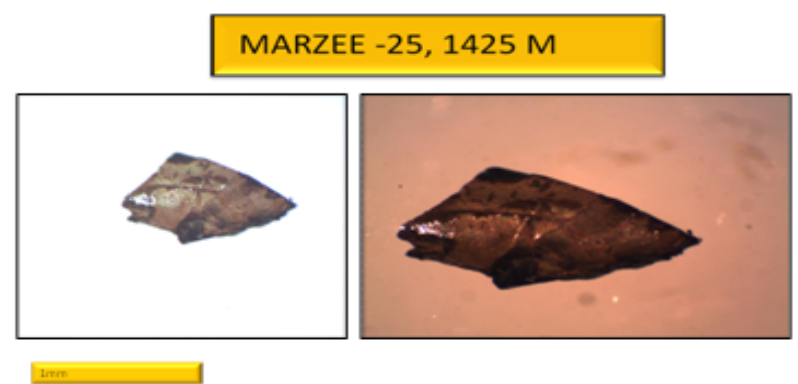

Figure 3. Microphotograph of oil mineral aggregates obtained from surface sediments from the continental slope of the NW Gulf of Mexico. the crude oil molecules, such as naphthalene, phenanthrene, benzenes, and also the trace elements such as vanadium, cadmium, chromium, zinc, lead, and nickel.

From an ecological point of view, it is important to recognize that the vast majority of organisms inhabiting the GoM conduct, as part of their life cycle, circadian and seasonal migratory movements at different spatial scales that could seriously be disturbed by the presence in the water column of spilled crude oil mixed with chemical dispersants (Corexit). The direct exposure, the disruption of breeding and spawning areas, or the transfer of contaminants through the food web, are just some of the deleterious effects one may expect to occur in the GoM due to the Macondo's blow out [28,29]. Considering the existing ecological connectivity within the GoM, it is doubtful to accept the argument that the conditions of environmental damage caused by the accidental oil spill in the northern gulf were spatially and temporally confined to that region.

The Ixtoc-1 (1979), Exxon Valdez (1989) and Prestige (2002) oils spill accidents are painful remainders of the lasting harmful effects to the marine ecosystem. Microbiologists were the first to report the unusual oil microbial degradation that contributed significantly to minimize the seriousness of the Macondo's oil spill in surface waters $[30,31]$. However, it was difficult to reconcile the bacterial degradation rate in deep-water with an average temperature of $4{ }^{\circ} \mathrm{C}$ and possibly anaerobic conditions in sediments. We presume that many of the toxic elements of crude oil still remain bio-available in the sediments of the GoM at sublethal levels mainly for benthic dwellers. Our current toxicity analyses in tissues of shelf-fauna inhabitants (mollusks, decapods crustaceans, and demersal fish) from the northwestern GoM reveal concentrations of HAP's and heavy metals not exceeding the levels to cause mortality $[32,33]$. However, the bioaccumulation effects and possible magnification in the trophic web cannot be ruled out.

On the other hand, prior to the accidental Macondo's oil spill, Mexican fisheries experts [34,35] have already sent warning signs about the overexploitation levels reached by demersal and finfish stocks traditionally exploited in Mexico's EEZ waters. An additional stress factor such as the presence of chemical pollutants in the GoM may seriously undermine the immune capacity of individuals and their bioenergetics balance (respiratory metabolism-growth-rate-reproduction).

Bearing in mind the legacy left by accidental oil spills occurred at different latitudes (IXTOC-1, 1979, SW Gulf of Mexico; EXXON Valdez, 1989, Alaska; PRESTIGE, 2002, northern coast of Spain), we could expect that the MACONDO massive oil spill effects will be present in the GoM for several decades. The restoration of the ecological stability of the GoM would depend on its resi- 
lience capacity. Indeed, the existing natural oil and gas seeps and the chronic contamination due to the current extraction of fossil fuels in the north and south of the GoM, increase the uncertainty in detecting the chemical fingerprint from MACONDO. However, the seriousness of the environmental damage of this unprecedented phenomenon in the annals of contemporary science cannot be met with hesitation or skepticism. An answer to this challenging issue can be found in the implementation of a modern observational system of oceanographic conditions of the GoM and the periodic determinations of oil biomarkers in sediments and biota $\left(\delta^{13} \mathrm{C}\right.$, PAHs, hopanes, steranes, and trace metals).

\section{Conclusions}

In the aftermath of the unfortunate Macondo's blowout in which nearly 5 million barrels of crude oil were spilled both in deep and surface waters of the northern GoM, a heated debate emerged among experts on the fate and persistence of the hydrocarbons in coastal and deep environments. The severe disruption of the ecological balance absorbed by the GoM due to this massive spill tended to be officially underrated by the contention and emergency procedures implemented during the acute phase of the accident. Natural processes such as evaporation, dispersion, dilution, and a significant microbial biodegradation were largely credited for the substantial loss of the released oil $(>74 \%)$. The remaining percentage still poses potential damages specially for the deep sea environment since we ignore the degradation rates of the different oil components, the areas of deposition, and the dispersion trajectories of subsurface oil plumes. Unfortunately, our current knowledge on the deep circulation patterns and the deep sea biodiversity of the GoM is not sufficient to foresee the degree and duration of the environmental disturbance that an input of crude oil may have in the Mexican EEZ. This is a challenging research issue that requires the best available science and multilateral cooperation from neighboring countries in the GoM. From a Mexican perspective, the answer to this riddle can be found in the rescue of historical data, and the implementation of a Monitoring Program of our coastal and oceanic waters in order to ensure the sustaining development of this LME.

\section{Acknowledgements}

We are indebted to the research group integrated in the project "Marco Ambiental de las Condiciones Oceanográficas en el Sector NW de la ZEE de México en el Golfo de México (MARZEE)” for their invaluable support and tireless enthusiasm. The authors would like to acknowledge the financial support of the Instituto Na- cional de Ecología y Cambio Climático (INECC).

\section{REFERENCES}

[1] "Deepwater Horizon Oil Spill Principal Investigator Workshop: Final Report,” National Science and Technology Council, Subcommittee on Ocean Science and Technology, Washington, DC, 2012.

http://www.marine.usf.edu/conferences/fio/NSTC-SOSTPI-2011/documents/SOST_2011_DWH_Workshop_Final _Report.pdf

[2] J. Lubchenco, M. McNutt, B. Lehr, M. Sogge, M. Miller, S. Hammond and W. Conner, "Deepwater Horizon/BP Oil Budget: What Happened to the Oil?” Silver Spring, MD: National Oceanic and Atmospheric Administration, 2010.

http://www.noaanews.noaa.gov/stories2010/PDFs/OilBud get_description_\%2083final.pdf

[3] P. S. Daling, "Weathering Properties at Sea of the Macondo MC252 Crude Oil,” Gulf Oil Spill SETAC Focused Topic Meeting, Merida, 2011, p. 39.

[4] K. M. Kleinow, A. Bui, L. J. Thibodeaux and S. M. FritzKleinow, "Effect of the Dispersant Corexit upon Bioavailability and Toxicity of Deep Horizon Light Crude Oil Emulsion Components to Developing Fish,” Gulf Oil Spill SETAC Focused Topic Meeting, Merida, 2011, p. 25.

[5] B. A, Muhling, et al., "Overlap between Atlantic bluefin tuna spawning grounds and observed Deepwater Horizon surface oil in the northern Gulf of Mexico," Marine Pollution Bulletin, Vol. 64, No. 4, 2012, pp. 679-687. http://dx.doi.org/10.1016/j.marpolbul.2012.01.034

[6] P. D. Boehm, et al., "Polynuclear Aromatic Hydrocarbons from MC252 in the Water Column: Preliminary Exposure Assessment, Weathering, and Biodegradation,” Gulf Oil Spill SETAC Focused Topic Meeting, Merida, 2011, p. 40.

[7] S. E. Allan, B. W. Smith and K. A. Anderson, "Impact of the Deepwater Horizon Oil Spill on Bioavailable Polycyclic Aromatic Hydrocarbons in Gulf of Mexico Coastal Waters," Environmental Science \& Technology, Vol. 46, No. 4, 2012, pp. 2033-2039.

http://dx.doi.org/10.1021/es202942q

[8] K. Sherman, "Sustainability, Biomass Yield, and Health of Coastal Ecosystems: An Ecological Perspective,” Marine Ecology Progress Series, No. 112, 1994, pp. 277-301. http://dx.doi.org/10.3354/meps112277

[9] A. R. Diercks, et al., "Characterization of Subsurface Polycyclic Aromatic Hydrocarbons at the Deepwater Horizon Site," Geophysical Research Letters, Vol. 37, 2010, pp. 1-6. http://dx.doi.org/10.1029/2010GL045046

[10] T. C. Hazen, et al., "Deep-Sea Oil Plume Enriches Indigenous Oil-Degrading Bacteria,” Science, Vol. 330, No. 6001, 2010, pp. 204-208. http://dx.doi.org/10.1126/science.1195979

[11] R. Camilli, et al., "Tracking Hydrocarbon Plume Transport and Biodegradation at Deepwater Horizon,” Science Express, 2010. http://dx.doi.org/10.1126/science.1195223 
[12] C. M. Reddy, et al., "Composition and Fate of Gas and Oil Released to the Water Column during the Deepwater Horizon Oil Spill," Proceedings of the National Academy of Sciences, Vol. 109, No. 50, 2012, pp. 20229-20234. http://dx.doi.org/10.1073/pnas.1101242108

[13] J. Zavala-Hidalgo, S. L. Morey and J. J. O’Brien, “Seasonal Circulation on the Western Shelf of the Gulf of Mexico Using a High-Resolution Numerical Model,” Journal of Geophysical Research, Vol. 108, 2003, pp. 1-19. http://dx.doi.org/10.1029/2003JC001879

[14] J. Zavala-Hidalgo, R. Romero-Centeno, E. Galvanovskis Romero, M. L. Lagunas Modesto and M. E. Osorio Tai, "Riesgo Ecológico y Modelo Predictivo de la Trayectoria de la Pluma Submarina de Hidrocarburo Procedente del Pozo Macondo (BP), Luisiana en la Zona Económica Exclusiva de México, Golfo de México,” Rep. Tec. CCA.UNAM, 2013, 35 p.

[15] I. R. MacDonald, "Natural Oil Spills,” Scientific American, No. 279, 2012, pp. 56-61.

[16] D. L. Valentine, et al., "Propane Respiration Jump-Starts Microbial Response to a Deep Oil Spill,” Science, Vol. 330, No. 6001, 2010, pp. 208-211. http://dx.doi.org/10.1126/science.1196830

[17] D. L. Valentine, et al., "Dynamic Autoinoculation and the Microbial Ecology of a Deep Water Hydrocarbon Irruption," Proceedings of the National Academy of Sciences, 2012, in press.

[18] T. B. Ryerson, et al., "Chemical Data Quantify Deepwater Horizon Hydrocarbon Flow Rate and Environmental Distribution," Proceedings of the National Academy of Sciences, 2012, in press. http://dx.doi.org/10.1073/pnas.1110564109

[19] A. V. Botello, et al., “Golfo de México: Contaminación e Impacto Ambiental : Diagnóstico y Tendencias ," Campeche: Universidad Autónoma de Campeche , Centro de Ecología, Pesquerías y Oceanografía del Golfo de México, Univ. Nal. Autó. Méx., Inst. Cien. Mar y Limnol., Inst. Nal. Ecol., 2005, p. 696.

[20] L. A. Soto and C. González Macías, "PEMEX y la Salud Ambiental de la Sonda de Campeche, México,” Luis A. Soto y Carmen González Macías, Eds., Batelle-IMPUAM-UNAM, 2009, 336 p.

[21] L. A. Soto, et al., "Marco Ambiental de las Condiciones Oceanográficas En El Sector NW de la Zee de México en El Golfo de México (Marzee),” Rep. Tec. I. UNAM-INE, 2011, 430 p.

[22] L. A. Soto, et al., "Marco Ambiental de las Condiciones Oceanográficas En El Sector NW de la Zee De México En El Golfo De México (Marzee),” Rep. Tec. II. UNAMINE, 2012, 430 p.

[23] N. N. Rabalais and R. E. Turner, "Hypoxia in the Northern Gulf of Mexico: Description causes and changes, in Coastal Hypoxia: Consequences for Living Resources and Ecosystems,” In: N. N. Rabalais and R. E. Turner, Eds., Coastal Estuarine Studies, Vol. 58, AGU, Washington, D. C., 2001, pp. 1-36.

\section{http://dx.doi.org/10.1029/CE058p0001}

[24] G. Ponce-Vélez, A. V. Botello and G. Díaz-González, "Organic and Inorganic Pollutants in Marine Sediments from Northern and Southern Continental Shelf of the Gulf of Mexico," International Journal of Environment and Pollution, Vol. 26, 2006, pp. 295-311. http://dx.doi.org/10.1504/IJEP.2006.009113

[25] U. R. Sumaila, et al., "Impact of the Deepwater Horizon Well Blowout on the Economics of US Gulf Fisheries," Canadian Journal of Fisheries and Aquatic Sciences, Vol. 69, No. 3, 2012, pp. 499-510. http://dx.doi.org/10.1139/f2011-171

[26] Sistema Satelital de Monitoreo Oceánico de la CONABIO: Reporte No. 1 -CONABIO.

http://www.conabio.gob.mx/informacion/geo_espanol/mo dis/oceano.html

[27] S. S. Figueroa, "Evaluación de la Toxicidad de Sedimentos," In: L. A. Soto, Ed., Proyecto "Marco Ambiental de las Condiciones Oceanográficas en el Sector NW de la zee de México en el Golfo de México (Marzee II)”, Rep. Tec. Ii. Unam. Inecc, México, 2012, 430 p.

[28] Greer, et al., "Is CEWAF Prepared in the Lab Suitable for Predicting Toxicity to Herring Embryos?” Gulf Oil Spill SETAC Focused Topic Meeting, Merida, 2011, p. 34.

[29] S. Mitra, et al., "Macondo-1 Well Oil-Derived Polycyclic Aromatic Hydrocarbons in Mesozooplankton from the Northern Gulf of Mexico," Geophysical Research Letters, Vol. 39, No. 1, 2012, pp. 1-6.

[30] T. C. Hazen, et al., "Deep-Sea Oil Plume Enriches Indigenous Oil-Degrading Bacteria,” Science Express, 2010, pp. 1-10.

[31] D. L. Valentine, et al., "Response to a Deep Oil Spill Propane Respiration Jump-Starts Microbial,” Science, Vol. 330, No. 208, 2010, pp. 208-211. http://dx.doi.org/10.1126/science.1196830

[32] A. V. Botello, et al., “Contaminación Marina,” L. A. Soto, Ed., PROYECTO In: L. A. Soto, Ed., Proyecto "Marco Ambiental de las Condiciones Oceanográficas en el Sector NW de la zee de México en el Golfo de México (Marzee II)”, Rep. Tec II. UNAM. INECC, México, 2012, $436 \mathrm{p}$.

[33] G. Núñez-Nogueira, et al., "Determinación de Metales en Biota” L. A. Soto, Ed., In: L. A. Soto, Ed., Proyecto “Marco Ambiental de las Condiciones Oceanográficas en el Sector NW de la zee de México en el Golfo de México (Marzee II)”, Rep. Tec II. UNAM. INECC, México, 2012, $436 \mathrm{p}$.

[34] A. Díaz de León, J. I. Fernández, P. Álvarez-Torres, O. Ramírez-Flores and L. G. López-Lemus, "La Sustentabilidad de las Pesquerías del Golfo de México," In: M. Caso, I. Pisanty and E. Ezcurra, Eds., Diagnóstico Ambiental del Golfo de México, SEMARNAT-INE-Harte Res. Inst., Vol. I-II, 2004, pp. 727-755.

[35] Díaz-Guzmán, et al., "Posibles Efectos del Derrame de Petróleo del Golfo de México en la Pesquería Mexicana del atún,” El Vigía, Vol. 15, No. 37, 2010, pp. 11-16. 